\title{
Exogenous application of phytohormones mitigates the effect of salt stress on Carica papaya plants
}

\author{
Francisco V. da S. Sá ${ }^{1}$, Marcos E. B. Brito ${ }^{2}$, Luderlândio de A. Silva³ ${ }^{3}$ Rômulo C. L. Moreira ${ }^{3}$, \\ Emanoela P. de Paiva ${ }^{1} \&$ Lauter S. Souto ${ }^{4}$
}

\begin{abstract}
${ }^{1}$ Universidade Federal Rural do Semi-Árido/Centro de Ciências Agrárias, Mossoró, RN, Brasil. E-mail: vanies_agronomia@hotmail.com (Corresponding author) - ORCID: 0000-0001-6585-8161; emanuelappaiva@hotmail.com - ORCID: 0000-0003-4510-9205

${ }^{2}$ Universidade Federal de Sergipe/Centro de Ciências Agrárias do Sertão/Núcleo de Graduação em Educação em Ciências Agrárias e da Terra, Nossa Senhora da Glória, SE, Brasil. E-mail: marcoseric@ufs.br - ORCID: 0000-0001-9087-3662

${ }^{3}$ Universidade Federal de Campina Grande/Centro de Tecnologia e Recursos Naturais/Unidade Acadêmica de Engenharia Agrícola, Campina Grande, PB, Brasil. E-mail: luderlandioandrade@gmail.com - ORCID: 0000-0001-9496-5820; romulocarantino@gmail.com - ORCID: 0000-0002-4079-4939

${ }^{4}$ Universidade Federal de Campina Grande/Centro de Ciências e Tecnologia Agroalimentar/Unidade Acadêmica de Ciências Agrárias, Pombal, PB, Brasil. E-mail: lauter@ccta.ufcg.edu.br - ORCID: 0000-0002-1053-0297
\end{abstract}

\begin{abstract}
The salinity has complex effects on the physiological, nutritional and hormonal interactions of plants. This study aimed to evaluate the mitigating action of exogenous application of different types and concentrations of phytohormones on Carica papaya under salt stress. The experiment was conducted in greenhouse, using a randomized block design with treatments formed from a $2 \times 3 \times 5$ factorial scheme, relative to two concentrations of salts in the irrigation water $\left(0.6\right.$ and $\left.2.4 \mathrm{dS} \mathrm{m}^{-1}\right)$, three types of phytohormones [Auxin = indole-3-acetic acid; Cytokinin = CPPU (N-(2-chloro-pyridyl)-N-phenylurea) and Gibberellin = gibberellic acid $\left.\left(\mathrm{AG}_{3}\right)\right]$, and five concentrations of the phytohormone $\left(0,12.5,25.0,37.5\right.$ and $\left.50.0 \mu \mathrm{M} \mathrm{L}^{-1}\right)$, with three repetitions, totaling 90 plots, and the experimental unit consisted of six plants. C. papaya cv. 'Sunrise Solo' was grown on polyethylene trays of 162 cells, with capacity for $50 \mathrm{~mL}$. The plants were evaluated for survival percentage and phytomass accumulation until 25 days after sowing. Increase in irrigation water salinity has deleterious effects on C. papaya plants regardless of the application of phytohormones. Exogenous application of gibberellin has a positive effect in mitigating salt stress on C. papaya plants, greater than the effects of auxins and cytokinins. Exogenous application of gibberellin and auxin at concentration of $37.5 \mu \mathrm{M}$ $\mathrm{L}^{-1}$ mitigates the effects of salinity on C. papaya plants. Exogenous application of cytokinin at concentrations of 12.5 to $50.0 \mu \mathrm{M} \mathrm{L}^{-1}$ is not viable for C. papaya plants.
\end{abstract}

Key words: auxins, cytokinins, gibberellins, salinity

\section{Aplicação exógena de fitormônios mitiga o efeito do estresse salino em plantas de Carica papaya}

\begin{abstract}
RESUMO: A salinidade tem efeitos complexos nas interações fisiológicas, nutricionais e hormonais das plantas. Objetivou-se avaliar a ação mitigadora da aplicação exógena de diferentes tipos e concentrações de hormônios vegetais em plantas de Carica papaya sob estresse salino. O experimento foi realizado em casa de vegetação por meio do delineamento experimental de blocos casualizados com tratamentos formados a partir de esquema fatorial $2 \times 3 \times 5$, relativo a duas concentrações de sais na água de irrigação $\left(0,6\right.$ e $\left.2,4 \mathrm{dS} \mathrm{m}^{-1}\right)$, três tipos de hormônios vegetais [Auxina = ácido indol-3-acético; Citocinina = CPPU (N-(2-cloro-piridil)-Nfeniluréia) e Giberelina = ácido giberélico $\left(\mathrm{AG}_{3}\right)$ ], e cinco concentrações do hormônio vegetal $(0 ; 12,5 ; 25,0$; $37,550,0 \mu \mathrm{M} \mathrm{L}^{-1}$ ), com três repetições, totalizando 90 parcelas; sendo a unidade experimental composta por seis plantas. O cultivo do C. papaya, cv. Sunrise Solo, foi realizado em bandejas de polietileno de 162 cédulas, com capacidade de $50 \mathrm{~mL}$. As plântulas foram avaliadas quanto a percentagem de sobrevivência e o acúmulo de fitomassa até aos 25 dias após semeadura. O aumento da salinidade da água de irrigação exerce efeitos danosos nas plantas de C. papaya independente da aplicação de hormônios vegetais. A aplicação exógena da giberelina tem efeito positivo na mitigação do estresse salino em plântulas de C. papaya, superiores aos efeitos das auxinas e citocininas. As aplicações exógenas de giberelina e auxina na concentração de $37,5 \mu \mathrm{M}$ $\mathrm{L}^{-1}$ mitigam os efeitos da salinidade sobre as plântulas de C. papaya. A aplicação exógena da citocinina nas concentrações de 12,5 a $50,0 \mu \mathrm{M} \mathrm{L}^{-1}$ é inviável para as plântulas de C. papaya.
\end{abstract}

Palavras-chave: auxinas, citocininas, giberelinas, salinidade 


\section{INTRODUCTION}

Carica papaya L. is a plant typical of tropical climate, belonging to the Caricaceae family, with great socioeconomic and food importance in Brazil and worldwide. Currently, Brazil is the second largest papaya producer in the world, being responsible for $12.5 \%$ of the global production, with annual production estimated at 1,582,638 tons (FAO, 2018). C. papaya plants are moderately sensitive to salt stress since Sá et al. (2013a,b), evaluating the initial growth of two $C$. papaya cultivars irrigated with saline water, state that waters with salinity above $2.0 \mathrm{dS} \mathrm{m} \mathrm{m}^{-1}$ are not suitable for irrigation of C. papaya in the seedling stage, drastically liming its growth.

The osmotic and ionic effects imposed by salt stress directly affect plant development, both by the limitation in water absorption and the toxicity by specific ions, especially sodium and chloride. Thus, excessive accumulation of salts has complex effects on the physiological, nutritional and hormonal interactions of plants (Muns \& Tester, 2008; Syvertsen \& Garcia-Sanchez, 2014; Taiz et al., 2015). Hormonal interactions are complex and several researchers currently use plant-growth regulators (phytohormones) to reduce or eliminate the negative effects of salinity and therefore try to maintain the rates of cell expansion and division, as well as the translocation of compatible solutes (Tabur \& Demir, 2010; Javid et al., 2011). Auxins and cytokinins are phytohormones indispensable for vitality, growth and development of plants, and any alteration affecting their synthesis and homeostasis leads to death of the plant tissue. These phytohormones have recently been shown to be able to control plant adaptation to salt stress (Ha et al., 2012; Taiz et al., 2015). Javid et al. (2011) observed that exogenous application of indole-3-acetic acid (auxin) and kinetin (cytokinin) increase the production and concentration of starch in rice cultivars subjected to salt stress. Gibberellin (GA) is a plant regulator with regulatory functions in growth, influencing the growth rates of leaves, internodes, hypocotyls and roots (Nelissen et al., 2012; Taiz et al., 2015; Ubeda-Tomás et al., 2009). Xu et al. (2016) found that exogenous application of gibberellic acid mitigates salt stress in the initial growth of Festuca arundinacea genotypes. Given the above, this study aimed to evaluate the mitigating action of exogenous application of different types and concentrations of phytohormones in C. papaya plants under salt stress.

\section{Material AND Methods}

The experiment was conducted in a greenhouse at the Centro de Ciências e Tecnologia Agro-alimentar da Universidade Federal de Campina Grande (CCTA-UFCG), Campus of Pombal, PB, located in the semi-arid region of Brazil (6 $6^{\circ} 48^{\prime} 16^{\prime \prime} \mathrm{S}, 37^{\circ} 49^{\prime} 15^{\prime \prime} \mathrm{W}$, at altitude of $175 \mathrm{~m}$ ).

The experimental design was randomized blocks, with treatments formed from a $2 \times 3 \times 5$ factorial scheme, relative to two concentrations of salts in the irrigation water based on water electrical conductivity (ECw) $\left(S_{1}=0.6\right.$ and $S_{2}=2.4 \mathrm{dS}$ $\mathrm{m}^{-1}$ ) (Sá et al., 2013b), three types of phytohormones [Auxin = indole-3-acetic acid; Cytokinin = CPPU (N-(2-chloro-pyridyl)$\mathrm{N}$-phenylurea) and Gibberellin = gibberellic $\left.\operatorname{acid}\left(\mathrm{AG}_{3}\right)\right]$, and five concentrations of phytohormone $(0,12.5,25.0,37.5$ and $50.0 \mu \mathrm{M} \mathrm{L}^{-1}$ ), which were repeated in three blocks, in a total of 90 plots, each one with six plants.

Plants were grown on polyethylene trays of 162 cells, with capacity for $50 \mathrm{~mL}$, washed with sodium hypochlorite at $10 \%$, containing substrate composed of a mixture of soil (Entisol fluvent) and commercial substrate (Top Plant ${ }^{\oplus}$ ), at 1:1 proportion, respectively, whose chemical characteristics were determined based on Donagema et al. (2011) and are described in Table 1.

The cultivar of C. papaya used in the experiment was 'Sunrise Solo', belonging to the group 'Solo', described as the most tolerant in a study conducted by Sá et al. (2013b), evaluating the tolerance to salt stress of C. papaya cultivars from the groups 'Solo' and 'Formosa' in the stage of seedling production. Sowing was carried out using three seeds per cell, and thinning was performed when plants had one true leaf, leaving only one plant in each pot. The period for seedling emergence stabilization was 15 days.

At 15 days after sowing, irrigations with salinized waters began and were performed twice a day, so as to maintain the soil with moisture content close to the maximum retention capacity, based on drainage lysimetry, and to the water depth calculated was added a leaching fraction (LF) of 0.20 (Sá et al., 2016). The volume applied (Va) per pot was obtained by the difference between the previous irrigation depth applied (La) and mean drainage (d), divided by the number of pots (n), as shown in Eq. 1:

$$
\mathrm{Va}=\frac{\mathrm{La}-\left(\frac{\mathrm{d}}{\mathrm{n}}\right)}{(1-\mathrm{LF})}
$$

Saline waters were prepared by the addition of salts to the local supply water, ECw $=0.27 \mathrm{dS} \mathrm{m}^{-1}$. The salts used in the water salinization process were $\mathrm{NaCl}, \mathrm{CaCl}_{2} .2\left(\mathrm{H}_{2} \mathrm{O}\right)$ and $\mathrm{MgCl}_{2} \cdot 6\left(\mathrm{H}_{2} \mathrm{O}\right)$, at proportion of $7 \times 2 \times 1$, respectively, as recommended by Medeiros (1992), because it represents the average composition of the waters in Northeast Brazil. The salts were added until obtaining the desired level of salinity, which was calibrated with a benchtop conductivity meter, and the electrical conductivity was adjusted at $25^{\circ} \mathrm{C}$.

Exogenous application of phytohormones was carried out as the irrigation with saline water began. The different concentrations of each phytohormone were prepared (diluted) in deionized water at the Laboratory of Plant Physiology of the Universidade Federal de Campina Grande. Phytohormones

Table 1. Chemical characteristics of the substrate used in the production of Carica papaya seedlings

\begin{tabular}{|c|c|c|c|c|c|c|c|c|c|c|c|c|}
\hline $\mathrm{K}^{+}$ & $\mathrm{Na}^{+}$ & $\mathrm{Ca}^{+2}$ & $\mathrm{Mg}^{+2}$ & $\mathrm{Al}^{+3}$ & $\mathrm{H}^{+}+\mathrm{Al}^{+3}$ & SB & CEC & \multirow{2}{*}{$\begin{array}{c}\mathrm{pH} \\
\left(\mathrm{H}_{2} \mathrm{O}\right)\end{array}$} & \multirow{3}{*}{$\begin{array}{c}\text { ECse } \\
\left(\mathrm{dS} \mathrm{m}^{-1}\right) \\
0.82\end{array}$} & \multirow{3}{*}{$\begin{array}{c}\mathbf{P} \\
\left(\mathrm{mg} \mathrm{dm}^{-3}\right) \\
19\end{array}$} & \multirow{2}{*}{$\begin{array}{l}\text { ESP } \\
(\%)\end{array}$} & \multirow{3}{*}{$\begin{array}{c}\text { OM } \\
\left(\mathrm{g} \mathrm{kg}^{-1}\right) \\
52\end{array}$} \\
\hline \multicolumn{8}{|c|}{$\left(\mathrm{cmol}_{\mathrm{c}} \mathrm{dm}^{-3}\right)$} & & & & & \\
\hline 0.45 & 0.34 & 9.20 & 7.50 & 0 & 1.16 & 17.49 & 17.49 & 6.42 & & & 1.82 & \\
\hline
\end{tabular}

P, $\mathrm{K}^{+}, \mathrm{Na}^{+}$- Extracted with Mehlich-1; $\mathrm{Al}^{+3}, \mathrm{Ca}^{+2}, \mathrm{Mg}^{+2}$ - Extracted with $1.0 \mathrm{~mol} \mathrm{~L}-1 \mathrm{KCl} ; \mathrm{SB}=\mathrm{Ca}^{+2}+\mathrm{Mg}^{+2}+\mathrm{K}^{+}+\mathrm{Na}^{+} ; \mathrm{H}^{+}+\mathrm{Al}^{+3}-\mathrm{Extracted}$ with 0.5 mol L-1 calcium acetate at pH 7.0 ; $\mathrm{CEC}=\mathrm{SB}+\mathrm{H}^{+}+\mathrm{Al}^{+3}$; OM - Walkley-Black wet digestion; ECse - Electrical conductivity of the saturation extract; ESP - Exchangeable sodium percentage 
were applied using manual sprayers on plant shoots, $15 \mathrm{~mL}$ per plot.

At 5 and 10 days of treatment application, corresponding to 20 and 25 days after sowing, the percentage of survival of C. papaya plants was determined based on the ratio between the number of living plants in the plot and the number of dead plants, with values expressed in percentage. At 10 days after applying the treatments, total dry matter accumulation (TDM) was determined. Plants were collected, placed in paper bags and dried in a forced-air oven at temperature of $65^{\circ} \mathrm{C}$ until constant weight. Then, the material was weighed on an analytical scale with $0.0001 \mathrm{~g}$ precision at the Laboratory of Plant Physiology of the Universidade Federal de Campina Grande.

At the end of the experiment, electrical conductivity and $\mathrm{pH}$ were measured in the saturation extract following the methodology of Richards (1954), and the data are shown in Table 2. It can be observed that, even with leaching fraction of 0.20 , substrate salinity increased from $0.82 \mathrm{dS} \mathrm{m}^{-1}$ at the beginning of the experiment to 1.65 and $3.4 \mathrm{dS} \mathrm{m}^{-1}$ at the end of the experiment, on average, due to the irrigation with saline waters of 0.6 and $2.4 \mathrm{dS} \mathrm{m}^{-1}$, respectively (Tables 1 and 2).

The obtained data were evaluated by analysis of variance (ANOVA) based on the significance of $F$ test ( $p \leq 0.05)$. In cases of significance, a test of means (Tukey, $p \leq 0.05$ ) was carried out for the factor salt concentrations in the water and types of phytohormones, whereas a regression analysis was performed for the factor concentrations of phytohormones, using the software SISVAR 5.6 (Ferreira, 2011).

Table 2. Chemical characteristics of the substrate used in the production of Carica papaya seedlings at the end of the experiment

\begin{tabular}{|c|c|c|c|}
\hline $\begin{array}{l}\text { Water salinity } \\
\text { (dS } \mathrm{m}^{-1} \text { ) }\end{array}$ & Phytohormones & $\begin{array}{c}\text { ECse } \\
\left(\mathrm{dS} \mathrm{m}^{-1}\right)\end{array}$ & pHse \\
\hline 0.6 & Auxin & 1.65 & 6.05 \\
\hline 0.6 & Cytokinin & 1.46 & 7.08 \\
\hline 0.6 & Gibberellin & 1.75 & 6.86 \\
\hline Mean & ---------- & 1.65 & 6.66 \\
\hline 2.4 & Auxin & 3.54 & 7.11 \\
\hline 2.4 & Cytokinin & 3.03 & 6.60 \\
\hline 2.4 & Gibberellin & 3.64 & 6.89 \\
\hline Mean & ----------.- & 3.40 & 6.87 \\
\hline
\end{tabular}

\section{Results AND Discussion}

There was significant interaction ( $\mathrm{p} \leq 0.05)$ between the factors salinity, types of phytohormones and concentrations of phytohormones on survival percentage at 25 DAS. The double interactions between salinity and types of phytohormones and between types of phytohormones and their concentrations had significant effects $(\mathrm{p} \leq 0.05)$ on survival percentage at 20 DAS and total dry matter. Total dry matter was also significantly affected ( $p \leq 0.05$ ) by the interaction between water salinity and phytohormone concentrations (Table 3 ).

Considering the effect of the interaction between water salinity levels and types of phytohormone on the survival percentage at $20 \mathrm{DAS}$, it can be observed that the increase in water salinity from 0.6 to $2.4 \mathrm{dS} \mathrm{m}^{-1}$ led to the death of approximately $50 \%$ of $C$. papaya plants (Figure $1 \mathrm{~A}$ ). Irrigation with high-salinity water increased substrate salinity from 0.82
Table 3. Summary of analysis of variance for survival percentage (SV) at 20 DAS and at 25 DAS, and total dry matter (TDM) of Carica papaya plants under salt stress and exogenous application of different concentrations and types of phytohormones

\begin{tabular}{|c|c|c|c|c|}
\hline \multirow{3}{*}{$\begin{array}{l}\text { Sources } \\
\text { of variation }\end{array}$} & \multirow{3}{*}{ DF } & \multicolumn{3}{|c|}{ Mean square } \\
\hline & & SV 20 days & SV 25 days & TDM \\
\hline & & \multicolumn{2}{|c|}{$(\%)$} & (mg) \\
\hline Block & 2 & $310.06^{\text {ns }}$ & $160.54^{\text {ns }}$ & $5.91^{\mathrm{ns}}$ \\
\hline Sal & 1 & $65809.95^{\star}$ & $47476.69 *$ & $4765.49^{\star}$ \\
\hline Phyt & 2 & $1569.91^{\star}$ & $43892.69 *$ & $1184.84^{*}$ \\
\hline Conc & 4 & $697.41^{\star}$ & $543.41^{\star}$ & $19.73^{\text {ns }}$ \\
\hline Sal $\times$ Phyt & 2 & $829.47^{\star}$ & $12796.02^{*}$ & $70.82^{\star}$ \\
\hline Sal $\times$ Conc & 3 & $204.05^{\mathrm{ns}}$ & $543.41 *$ & $60.16^{*}$ \\
\hline Phyt $\times$ Conc & 8 & $503.10^{*}$ & $228.67^{\star}$ & $46.25^{\star}$ \\
\hline Sal $\times$ Phyt $\times$ Conc & 8 & $195.00^{\text {ns }}$ & $228.67^{\star}$ & $33.84^{\text {ns }}$ \\
\hline Error & 58 & 130.20 & 96.58 & 21.41 \\
\hline CV (\%) & - & 15.96 & 22.49 & 16.32 \\
\hline Mean & - & 71.47 & 43.70 & 28.35 \\
\hline
\end{tabular}

Sal - Salinity levels; Phyt - Phytohormones; Conc - Concentrations; DF - Degrees of freedom; CV - Coefficient of variation; ${ }^{\text {ns }}$ Not significant and ${ }^{*}$ - Significant at $p \leq 0.05$

A.

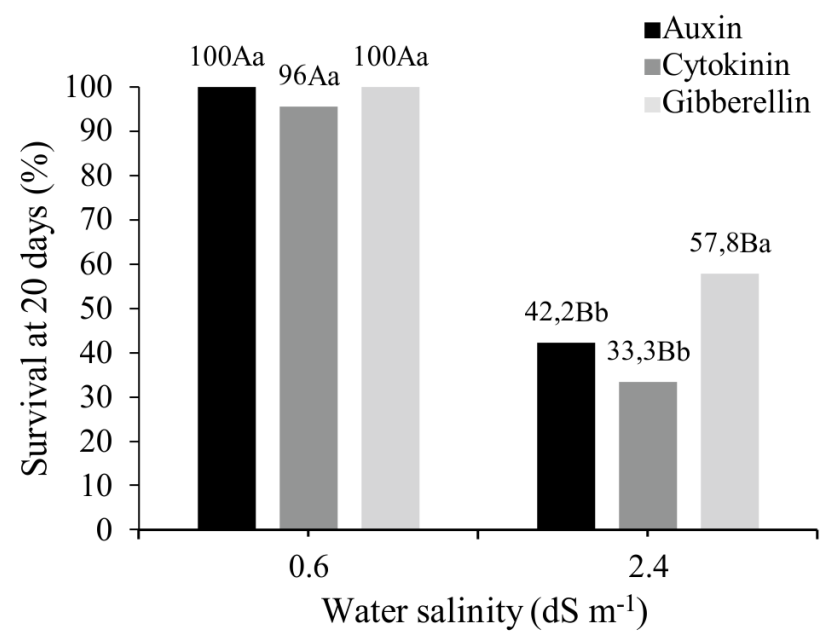

B.

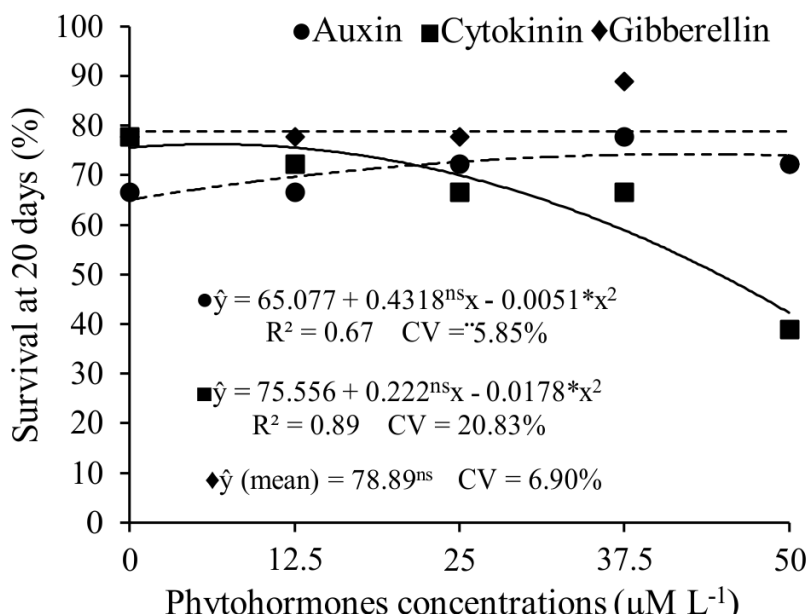

${ }^{*}$ and ${ }^{n s}$ - Significant at $\mathrm{p} \leq 0.05$ and not significant, respectively; Uppercase letters compare salinity levels for each type of phytohormone and lowercase letters compare phytohormones at each salinity level

Figure 1. Survival percentage of Carica papaya plants at 20 days after application of treatments: interaction between salinity and types of phytohormones (A) and interaction between types of phytohormones and concentrations of phytohormones (B) 
to $3.4 \mathrm{dS} \mathrm{m}^{-1}$ and this increment is due to the small volume of substrate, which was easily salinized to critical levels for the $C$. papaya crop. According to Sá et al. (2013a), C. papaya plants are highly sensitive to water electrical conductivity above 2.0 $\mathrm{dS} \mathrm{m}^{-1}$ in the initial growth stage. However, plants receiving exogenous application of gibberellin obtained higher survival percentage compared with those in the other treatments, with $57 \%$ of survival (Figure 1A).

In the interaction between types of phytohormones and their concentrations, there was no significant fit of survival percentage at the levels of gibberellin, and a mean survival of $78.89 \%$ was found at 20 days after treatment application (Figure 1B). Auxin application up to concentration of 42.3 $\mu \mathrm{M} \mathrm{L}^{-1}$ increased the survival percentage of $C$. papaya plants by $9.7 \%$ (Figure 1B). Exogenous application of cytokinin above the estimated concentration of $6.2 \mu \mathrm{M} \mathrm{L}^{-1}$ reduced the survival percentage of C. papaya plants, reaching values lower than $40 \%$ of living plants at 20 days after application of $50.0 \mu \mathrm{M} \mathrm{L}^{-1}$ of cytokinin, applied in the form of CPPU (Figure 1B).

For survival percentage at 10 days after treatment application, it can be noted that the increase in water salinity from 0.6 to $2.4 \mathrm{dS} \mathrm{m}^{-1}$ caused death of $100 \%$ of C. papaya plants which received exogenous application of phytohormone (Table 4). The effect of salt stress on C. papaya plants was progressively intensified by irrigation with high-salinity water, reaching levels that are unviable for this species.

On the other hand, exogenous application of $37.5 \mu \mathrm{M} \mathrm{L}^{-1}$ of auxin and particularly gibberellin were efficient at maintaining the vigor and tolerance of C. papaya plants to the salt stress, leading to survival percentages of 33.3 and $77.8 \%$, respectively (Table 4).

Exogenous application of cytokinin within the range used here (12.5 to $50.0 \mu \mathrm{M} \mathrm{L}^{-1}$ ) is not viable for C. papaya, as $100 \%$ of the plants died even in the absence of salt stress. Since cytokinins are responsible for regulating the rates of

Table 4. Test of means for survival percentage of Carica papaya plants at 25 days after being subjected to salt stress and exogenous applications of different concentrations and types of phytohormones

\begin{tabular}{|c|c|c|c|}
\hline \multicolumn{4}{|c|}{ Survival at 25 days (\%) } \\
\hline \multirow{2}{*}{ Phytohormones } & \multirow{2}{*}{$\begin{array}{c}\text { Concentrations } \\
\left(\mu \mathrm{M} \mathrm{L}^{-1}\right)\end{array}$} & \multicolumn{2}{|c|}{ Water salinity ( $\mathrm{dS} \mathrm{m}^{-1}$ ) } \\
\hline & & 0.6 & 2.4 \\
\hline \multirow{5}{*}{ Auxin } & 0.0 & $100.0 \times A a$ & 0.0 yAb \\
\hline & 12.5 & $100.0 \times A a$ & $22.2 \mathrm{yBab}$ \\
\hline & 25.0 & $100.0 \times A a$ & $22.2 \mathrm{yBab}$ \\
\hline & 37.5 & $100.0 \times A a$ & $33.3 \mathrm{yBa}$ \\
\hline & 50.0 & $100.0 \times A a$ & 22.2 yAab \\
\hline \multirow{5}{*}{ Cytokinin } & 0.0 & $96.0 \times A a$ & $0.0 \mathrm{yAa}$ \\
\hline & 12.5 & $0.0 \times B b$ & $0.0 \times \mathrm{Ca}$ \\
\hline & 25.0 & $0.0 \times B b$ & $0.0 \times \mathrm{Ca}$ \\
\hline & 37.5 & $0.0 \times B b$ & $0.0 \times \mathrm{Ca}$ \\
\hline & 50.0 & $0.0 \times \mathrm{Bb}$ & $0.0 \times \mathrm{Ba}$ \\
\hline \multirow{5}{*}{ Gibberellin } & 0.0 & $100.0 \times A a$ & 0.0 yAb \\
\hline & 12.5 & $100.0 \times A a$ & 44.4 yAb \\
\hline & 25.0 & $100.0 \times A a$ & 44.4 yAb \\
\hline & 37.5 & $100.0 \times A a$ & $77.8 \mathrm{yAa}$ \\
\hline & 50.0 & $100.0 \times A a$ & 22.2 yAb \\
\hline
\end{tabular}

${ }^{* *} \mathrm{x}$ and $\mathrm{y}$ letters in the row compare the interaction of salinity for each phytohormon $\mathrm{x}$ concentrations; uppercase letters $\mathrm{A}, \mathrm{B}$ and $\mathrm{C}$ in the column compare the interaction of phytohormones at each salinity $\mathrm{x}$ concentrations; lowercase letters $\mathrm{a}, \mathrm{b}$ and $\mathrm{c}$ in the column compare concentrations at each salinity $\mathrm{x}$ phytohormones, by Tukey test at $\mathrm{p} \leq 0.05$ cell division and expansion (Taiz et al., 2015) and considering that plants in the present study under exogenous application of cytokinin tripled their size in the first two days after phytohormone application, there may have been an inordinate synthesis and expansion of cells, which may have led to excessive absorption of water and salts from the substrate, causing death.

In addition, lower concentration of salts was observed in the substrate cultivated with plants under cytokinin application, probably due to the absorption by plants (Table 2 ).

Thus, absorption and excessive accumulation of salts in the tissues consequently led to ionic imbalance at levels which caused plant death. Absorption and excessive accumulation of salts can also be related to the capacity and/or function of cytokinins to facilitate the absorption of nutrients by the plant (Taiz et al., 2015).

Auxins and cytokinins are different from the other phytohormones because they are signaling agents necessary to make metabolism viable (Taiz et al., 2015). Thus, any mutation or external factor which limits their synthesis will lead to plant death, as observed in plants that did not receive exogenous application of these phytohormones in the presence of salt stress (Table 4). On the other hand, the synthesis of gibberellins is conditioned by the genetic factor, which is greatly influenced by the environmental factor (Taiz et al., 2015), the salt stress in the present study.

Thus, since plant metabolism maintains cytokinin at satisfactorily concentrations, the exogenous application of this phytohormone (high concentrations) caused physiological disorders in C. papaya plants, including toxicity (Table 4). Smaller damage was observed in plants under exogenous application of auxin, compared with those under exogenous application of cytokinin (Table 4). Although plant metabolism maintenance is also conditioned on optimal levels of auxin in the tissues, exogenous application of auxin may signal and stimulate the synthesis of gibberellins (Taiz et al., 2015), thus causing less deleterious effects on the metabolism of C. papaya plants, in comparison with cytokinins (Table 4).

In a study by Javid et al. (2011), it was reported that exogenous application of indole-3-acetic acid (auxin) and kinetin (cytokinin) increased the production and concentration of starch in rice cultivars subjected to salt stress, in comparison to the control. Exogenous application of auxins and cytokinins probably promotes better responses in grasses and limited responses in dicotyledons.

As already cited previously, the synthesis of gibberellins is conditioned by genetic factors, which are influenced by the environment. Therefore, it can be concluded that the synthesis of gibberellins in C. papaya plants under salt stress is limited, and the exogenous application of this phytohormone can benefit C. papaya plants by increasing their vigor and tolerance to salt stress. Xu et al. (2016), evaluating the exogenous application of gibberellic acid to mitigate salt stress in genotypes of Festuca arundinacea, found that it reduced the effect of the stress on leaf production and expansion rates. These authors also found that the exogenous application of this phytohormone stimulated the expression of four genes (xyloglucan endotransglycosylase 1 and 3, expansin A4 and A7) responsible for the increase in the tolerance of these plants to salinity. 
Based on the production of total phytomass in C. papaya plants affected by the interaction between salinity and types of phytohormones, it can be observed that the exogenous application of cytokinin led to lower accumulation of dry matter compared to the other phytohormones, regardless of salinity (Figure 2A). This fact is related to the excessive

A.

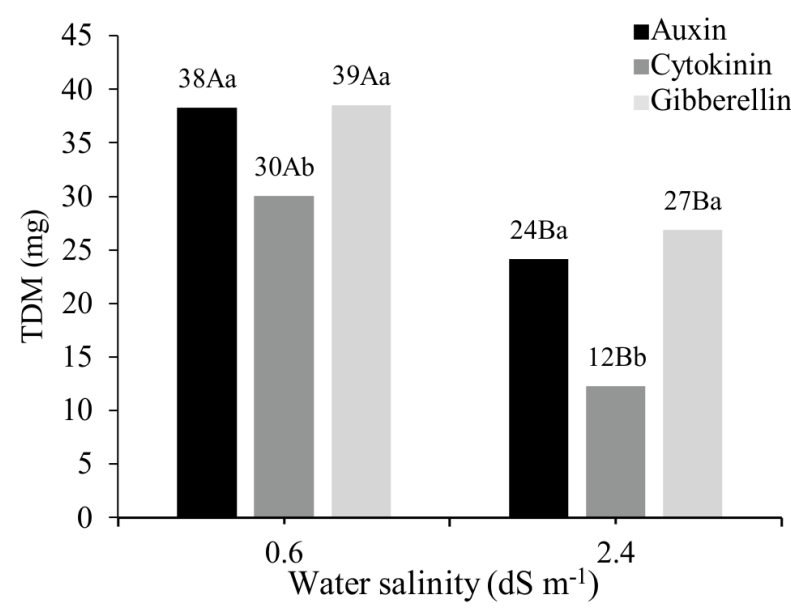

B.

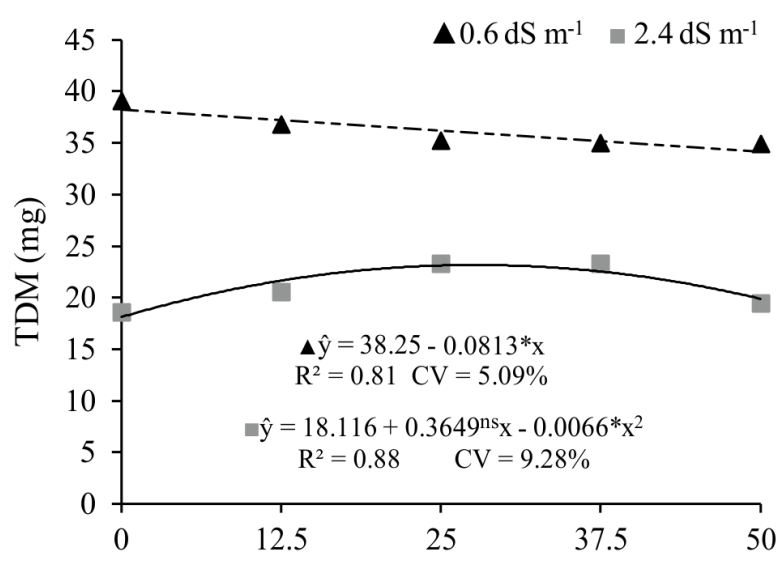

Phytohormones concentrations $\left(\mu \mathrm{M} \mathrm{L}^{-1}\right)$

C.

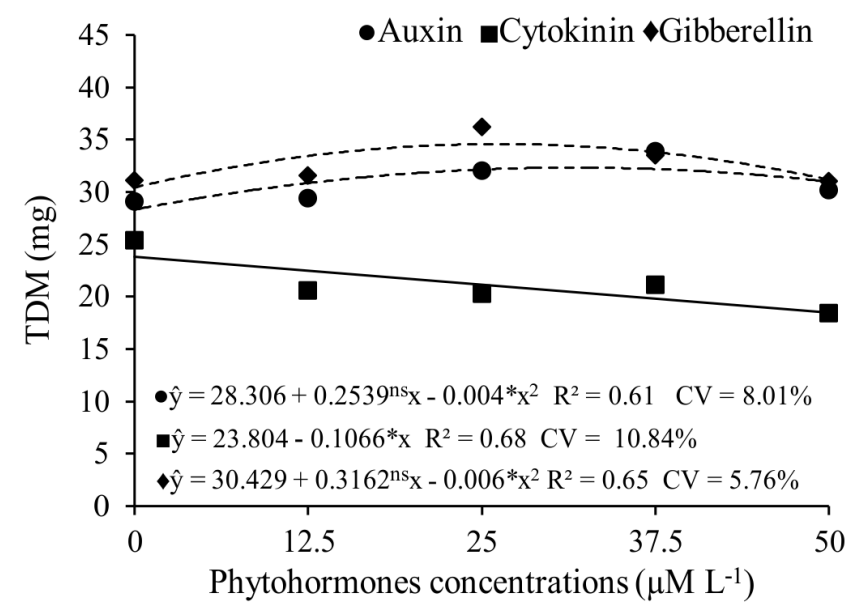

${ }^{*}$ and ${ }^{\mathrm{ns}}$ Significant at $\mathrm{p} \leq 0.05$ and not significant, respectively; Uppercase letters compare salinity for each type of phytohormone and lowercase letters compare phytohormones at each salinity

Figure 2. Total dry matter (TDM) of Carica papaya plants at 10 days after treatment application: interaction between salinity and types of phytohormones (A); interaction between salinity and concentrations of phytohormones (B) and interaction between types of phytohormones and their concentrations (C) absorption of water, caused by the high cell expansion rate in this treatment, which caused plants to be mainly composed of water, showing a low accumulation of photoassimilates. There was no significant difference in the dry matter accumulation between plants under exogenous applications of auxin and gibberellin (Figure 2A).

In general, the increase in salinity reduced the dry matter accumulation of $C$. papaya plants, regardless of the exogenous application of phytohormones (Figures $2 \mathrm{~A}$ and $\mathrm{B}$ ). The reduction in phytomass accumulation in C. papaya plants under salt stress has also been reported by Sá et al. (2013a,b; 2016). These authors attribute such reduction to the osmotic and ionic effects caused by the excessive accumulation of salts in the substrate. The osmotic and ionic effects imposed by the salt stress directly affect plant development, by either limiting water absorption or through the toxicity by specific ions, particularly sodium and chloride ones. Excessive accumulation of salts has complex effect on the physiological, nutritional and hormonal interactions of plants (Munns \& Tester, 2008; Syvertsen \& Garcia-Sanchez, 2014; Taiz et al., 2015).

In the interaction between salinity and concentrations of phytohormone, there was a progressive linear reduction of dry matter accumulation in plants irrigated with low-salinity water as the concentration of phytohormone increased. However, in plants irrigated with high-salinity water, a quadratic behavior was observed, and highest dry matter accumulation (23.31 $\mathrm{mg}$ ) was found at phytohormone concentration of $27.6 \mu \mathrm{M}$ $\mathrm{L}^{-1}$ (Figure 2B). Cunha et al. (2016) and Souza Neta et al. (2018) observed that the use of the biostimulant Stimulate ${ }^{\circledast}$, composed of a mixture of substances $[0.005 \%$ of indolebutyric acid (auxin), $0.009 \%$ of kinetin (cytokinin) and $0.005 \%$ of gibberellic acid (gibberellin)], was not efficient at mitigating the effect of salinity on sweet corn and gherkin, and found benefits only in plants grown in the absence of salt stress. The opposite was observed in the present study, which may be related to the low concentration of phytohormones in the biostimulant evaluated by these authors.

In the interaction between types and concentrations of phytohormones, cytokinin application caused a linear reduction in dry matter accumulation, whereas the concentrations of auxin and gibberellin caused a quadratic effect, with highest dry matter accumulation at concentrations of 31.7 and 26.4 $\mu \mathrm{M} \mathrm{L}^{-1}$, respectively (Figure $2 \mathrm{C}$ ).

It should be highlighted that the highest survival rate was found at concentration of $37.5 \mu \mathrm{M} \mathrm{L}^{-1}$ of gibberellin, which had the greatest potential to mitigate salt stress on C. papaya plants (Table 4). Thus, the greater survival of plants at the concentration of $37.5 \mu \mathrm{M} \mathrm{L}^{-1}$ of gibberellin under salt stress conditions is probably conditioned by a high expenditure of energy to promote ionic homeostasis, affecting the accumulation of photoassimilates.

Gibberellins play an essential role in plant growth and development, including seed germination, stem elongation, leaf expansion, production of flowers and development of fruits. In addition, exogenous application of gibberellins has been able to enhance the performance of plants under salt stress conditions (Khan et al., 2012; Iqbal \& Ashraf, 2013; Chunthaburee et al., 2014). Chunthaburee et al. (2014), evaluating the pretreatment of rice seeds with gibberellic acid subjected to salt 
stress, observed that exogenous application of gibberellin enhances the growth of all rice cultivars evaluated under salt stress, and the effects had greater potential in the sensitive cultivars. These authors also observed that the pre-soaking of seeds in gibberellic acid contributed to improvements in ionic homeostasis and delay in the loss of pigments, besides reinforcing the antioxidant systems, by reducing the production of $\mathrm{H}_{2} \mathrm{O}_{2}$, in rice plants exposed to salt stress.

\section{Conclusions}

1. The increase in irrigation water salinity has deleterious effects on C. papaya plants, regardless of the application of phytohormones.

2. Exogenous application of gibberellin has greater potential to mitigate salt stress in C. papaya plants in comparison to auxins and cytokinins.

3. Exogenous application of gibberellin (gibberellic acid) and auxin (indole-3-acetic acid) at concentration of $37.5 \mu \mathrm{M}$ $\mathrm{L}^{-1}$ mitigates the effects of salinity on C. papaya plants.

4. Exogenous application of cytokinin (N-(2-chloropyridyl)-N-phenylurea) at concentrations of 12.5 to $50.0 \mu \mathrm{M}$ $\mathrm{L}^{-1}$ is not viable for C. papaya plants.

\section{Literature Cited}

Chunthaburee, S.; Sanitchon, J.; Pattanagul, W.; Theerakulpisut, P. Alleviation of salt stress in seedlings of black glutinous rice by seed priming with spermidine and gibberellic acid. Notulae Botanicae Horti Agrobotanici, v.42, p.405-413, 2014. https://doi. org/10.15835/nbha4229688

Cunha, R. C.; Oliveira, F. A.; Souza, M. W. L.; Medeiros, J. F.; Lima, L. A.; Oliveira, M. K. T. Ação de bioestimulante no desenvolvimento inicial do milho doce submetido ao estresse salino. Irriga, v.edição especial, p.191-204, 2016. https://doi.org/10.15809/ irriga.2016v1n01p191-204

Donagema, G. K.; Campos, D. V. B.; Calderano, S. B.; Texeira, W. G.; Viana, J. H. M. Manual de métodos de análise de solo. 2.ed. Rio de Janeiro: Embrapa Solos, 2011. 230p.

FAO - Food and Agriculture Organization of the United Organizations. Production - Crops primary. Available on: <http://faostat.fao. org/>. Accessed on: Jul. 2018.

Ferreira, D. F. Sisvar: A computer statistical analysis system. Ciência e Agrotecnologia, v.35, p.1039-1042, 2011. https://doi.org/10.1590/ S1413-70542011000600001

Ha, S.; Vankova, R.; Yamaguchi-Shinozaki, K.; Shinozaki, K.; Tran, L. S. Cytokinins: Metabolism and function in plant adaptation to environmental stresses. Trends in Plant Science, v.17, p.172-179, 2012. https://doi.org/10.1016/j.tplants.2011.12.005

Iqbal, M.; Ashraf, M. Gibberellic acid mediated induction of salt tolerance in wheat plants: Growth, ionic partitioning, photosynthesis, yield and hormonal homeostasis. Environmental and Experimental Botany, v.86, p.76-85, 2013. https://doi. org/10.1016/j.envexpbot.2010.06.002

Javid, M. G.; Sorooshzadeh, A.; Sanavy, S. A. M. M.; Allahdadi, I.; Moradi, F. Effects of the exogenous application of auxin and cytokinin on carbohydrate accumulation in grains of rice under salt stress. Plant Growth Regulation, v.65, p.305-313, 2011. https:// doi.org/10.1007/s10725-011-9602-1
Khan, H. A.; Ziaf K.; Amjad, M.; Iqbal, Q. Exogenous application of polyamines improves germination and early seedling growth of hot pepper. Chilean Journal of Agricultural Research, v.72, p.429433, 2012. https://doi.org/10.4067/S0718-58392012000300018

Medeiros, J. F. de. Qualidade da água de irrigação e evolução da salinidade nas propriedades assistidas pelo "GAT" nos Estados do RN, PB e CE. Campina Grande UFCG, 1992. 173p. Dissertação de Mestrado

Munns, R.; Tester, M. Mechanism of salinity tolerance. Annual Review of Plant Biology, v.59, p.651-681, 2008. https://doi.org/10.1146/ annurev.arplant.59.032607.092911

Nelissen, H.; Rymen, B.; Jikumaru, Y.; Demuynck, K.; Lijsebettens, M. van; Kamiya, Y.; Inzé, D.; Beemster, G. T. A local maximum in gibberellin levels regulates maize leaf growth by spatial control of cell division. Current Biology, v.22, p.1183-1187, 2012. https:// doi.org/10.1016/j.cub.2012.04.065

Richards, L. A. Diagnosis and improvement of saline and alkali soils. Washington: U.S, Department of Agriculture, 1954. 160p. Handbook 60

Sá, F. V. S.; Brito, M. E. B.; Melo, A. S.; Antonio Neto, P.; Fernandes, P. D.; Ferreira, I. B. Produção de mudas de mamoeiro irrigadas com água salina. Revista Brasileira de Engenharia Agrícola e Ambiental, v.17, p.1047-1054, 2013a. https://doi.org/10.1590/ S1415-43662013001000004

Sá, F. V. da S.; Brito, M. E. B.; Moreira, R. C. L.; Melo, A. S. de; Silva, L. de A.; Gheyi, H. R.; Figueiredo, L. C. de; Paiva, E. P. de. Balance of salts and growth of papaya cultivars irrigated with saline water. Bioscience Journal, v.32, p.849-856, 2016. https:// doi.org/10.14393/BJ-v32n4a2016-32753

Sá, F. V. S.; Pereira, F. H. F.; Lacerda, F. H. D.; Silva, A. B. Crescimento inicial e acúmulo de massa seca de cultivares de mamoeiro submetidas à salinidade da água em cultivo hidropônico. Revista Brasileira de Ciências Agrárias, v.8, p.435-440, 2013b. https://doi. org/10.5039/agraria.v8i3a2663

Souza Neta, M. L.; Oliveira, F. A.; Torres, S. B.; Souza, A. A. T.; Silva, D. D. A.; Santos, S. T. Gherkin cultivation in saline medium using seeds treated with a biostimulant. Acta Scientiarum. Agronomy, v.40, p.59-68, 2018. https://doi.org/10.4025/actasciagron. v40i1.35216

Syvertsen, J. P.; Garcia-Sanchez, F. Multiple abiotic stresses occurring with salinity stress in citrus. Environmental and Experimental Botany, v.103, p.128-137, 2014. https://doi.org/10.1016/j. envexpbot.2013.09.015

Tabur, S.; Demir, K. Role of some growth regulators on cytogenetic activity of barley under salt stress. Plant Growth Regulation, v.60, p.99-104, 2010. https://doi.org/10.1007/s10725-009-9424-6

Taiz, L.; Zeiger, E.; Møller, I. M.; Murphy, A. Plant physiology and development. 6.ed. New York: Sinauer Associates, 2015. 761p.

Ubeda-Tomás, S.; Federici, F.; Casimiro, I.; Beemster, G. T.; Bhalerao, R.; Swarup, R.; Doerner, P.; Haseloff, J.; Bennett, M. J. Gibberellin signaling in the endodermis controls Arabidopsis root meristem size. Current Biology, v.19, p.1194-1199, 2009. https://doi. org/10.1016/j.cub.2009.06.023

Xu, Q.; Burgess, P.; Xu, J.; Meyer, W.; Huang, B. Osmotic stress and salt stress-inhibition and gibberellin-mitigation of leaf elongation associated with up-regulation of genes controlling cell expansion. Environmental and Experimental Botany, v.131, p.101-109, 2016. https://doi.org/10.1016/j.envexpbot.2016.06.001 